\title{
Poor Rural Cocoa Producers in Cameroon
}

\author{
Mbah Alma Andoh ${ }^{*}$, Mobit Joshua Mbah \\ Federation of Environmental and Ecological Diversity for Agricultural Revampment and Human Right (FEEDAR \& HR), Cameroon
}

Copyright $(2018$ by authors, all rights reserved. Authors agree that this article remains permanently open access under the terms of the Creative Commons Attribution License 4.0 International License

\begin{abstract}
Cocoa remains the main cash crop to more than $75 \%$ of the population of Cameroon. It is produced mainly by peasant farmers who even though they are the main producers of the highly demanded crop, do not earn sufficient income to meet their needs and maintain a moderate standard of living. This study aims at determining the economic status of Cameroon's rural people. Field visits were carried out in 10 villages in MEME Division with at least 5 experts spending at least one week in these villages. This was to assess the average quantity of cocoa that a farmer in the rural area produces; how they manage their cocoa farms; how they manage their income and if they keep records. Results show that an average farmer in the rural area produces 32.3 bags of cocoa yearly but they lack knowledge on how to manage their income since there are no banks in the villages. Only $11.2 \%$ save their monies in banks in the cities, $25.4 \%$ save theirs in "njangi" houses while the remaining $64.4 \%$ do not save at all. These make them to mishandle their income and they are forced to borrow chemicals for the next planting season causing the buyers to be the one to determine the price of the cocoa they produce. $84.1 \%$ borrows chemicals from their buyers, $15.3 \%$ keeps detailed records while $84.7 \%$ does not and this makes them unaware of if they are losing or gaining. In order to change their economic status, they have to be encouraged to create and/or join farmers groups that would enable them to better market their produce, educate them on the importance of saving, better agricultural practices, and how to keep good records.
\end{abstract}

Keywords Cocoa Producer, Rural, Cameroon, Poor, Field Survey

\section{Intoduction}

Cameroon's population by January 2017 was estimated to be $24,260,003$ and counting and 45.6 of this people live in rural areas. Cocoa remains the main cash crop to more than $75 \%$ of the population of Cameroon. It is produced mainly by peasant farmers who even though they are the main producers of this highly demanded crop, do not earn sufficient income to meet their needs and maintain a moderate standard of living.

In Cameroon the cocoa production has almost doubled in the last decade to the current level of about 220,000 tons. The average yield is low, about $300-400 \mathrm{~kg}$ per ha. About two-thirds of the developing world's 3 billion rural people live in about 475 million small farm households, working on land plots smaller than 2 hectares (Nagayets O, 2005). Many are poor and food insecure and have limited access to markets and services. The main yield limiting factors are the age of the cocoa trees, an inadequate input supply system and climatic conditions (V. Ngo Nkelle, 2007). Due to high rainfall during the cropping season the Phytophthora pod rot (black pod) disease causes great yield losses in the shaded (agroforestry) cocoa farms which can only be controlled by very frequent spraying with copper fungicides. This is expensive and not totally effective, and in practice little fungicide is used (D. Alemagi et al, 2004). The high rainfall also causes post-harvest losses due to inadequate drying and storage facilities. Only $10 \%$ of cocoa farmers operate under high technology that can guarantee yield of about $1400 \mathrm{~kg} / \mathrm{ha}$ (CRIG, 2010).

Computable general equilibrium (CGE) models typically use data on the production structure of a given country to estimate how an economy responds to a shock or a change in policy. Several country level CGE models demonstrate the multiplier effects of agricultural growth in other sectors of the economy (Coxhead and Warr 1991, De Franco and Godoy 1993, Datt and Ravallion 1996). As Poorer households appear to benefit more than less poor households from a $1 \%$ increase in GDP, in terms of increases expenditure. Furthermore, agriculturally driven growth generates a larger welfare effect than non-agriculturally driven growth, especially for the poorest $20 \%$ of the population (World Bank 2007). Irz et al. (2001) find that the most direct contribution of agricultural (sector) growth is through generating higher incomes for farmers.

Review shows that low yield is caused by low input use, inadequate maintenance and pest and disease control, poor shade management, little or no fertilizer use and old age of cocoa farms. How these factors cause low yields is shown 
in (ig. 1). In this model the farm gate cocoa price, high input prices, no access to loans and credits and the small farm size are considered as external factors beyond the control of the individual farmer. They affect the general conditions for cocoa production but have no direct effect on yield. Direct effects have the constraints and options for higher yields which operate within the cropping system.

Cocoa farming was introduced in the Mount Fako region of Cameroon in 1886 by the Germans with the aim of supplying their local factories with raw materials (cocoa beans). They owned and managed vast hectares of cocoa plantations which were worked forcefully by indigenous slaves. After the spread of the crop across the Southern part of the national territory, and the takeover of management by the French and British, cocoa farms were increasingly owned and managed by the peasants but were still maintained for export purposes. Since its independence in the 1960s up until recent years, cocoa production in Cameroon has been championed by smallholders on between 1 and 3 hectares of land.

In 2000, a survey revealed that their farms were underproductive because of ageing cocoa trees (40 years on average). The economic lifespan of cocoa trees varies from 25 to 40 years, depending on the variety. At the age of 40 the tree productivity is low compared to 10 years of age (cocoa productivity follows a bell shape distribution function). A transplanted tree requires 4 years to produce fruit. It is different from variety to variety, but on average, the first harvest is almost negligible, although grows exponentially until about 10 years of age, then begins to decline at about 20 years of age.

Among the social factors that led to the under productivity was the physical old age of the cocoa farmers as a result of rural-urban exodus of youths and the lack of attention and maintenance of the farms due to extended periods of low market prices for cocoa beans. This study

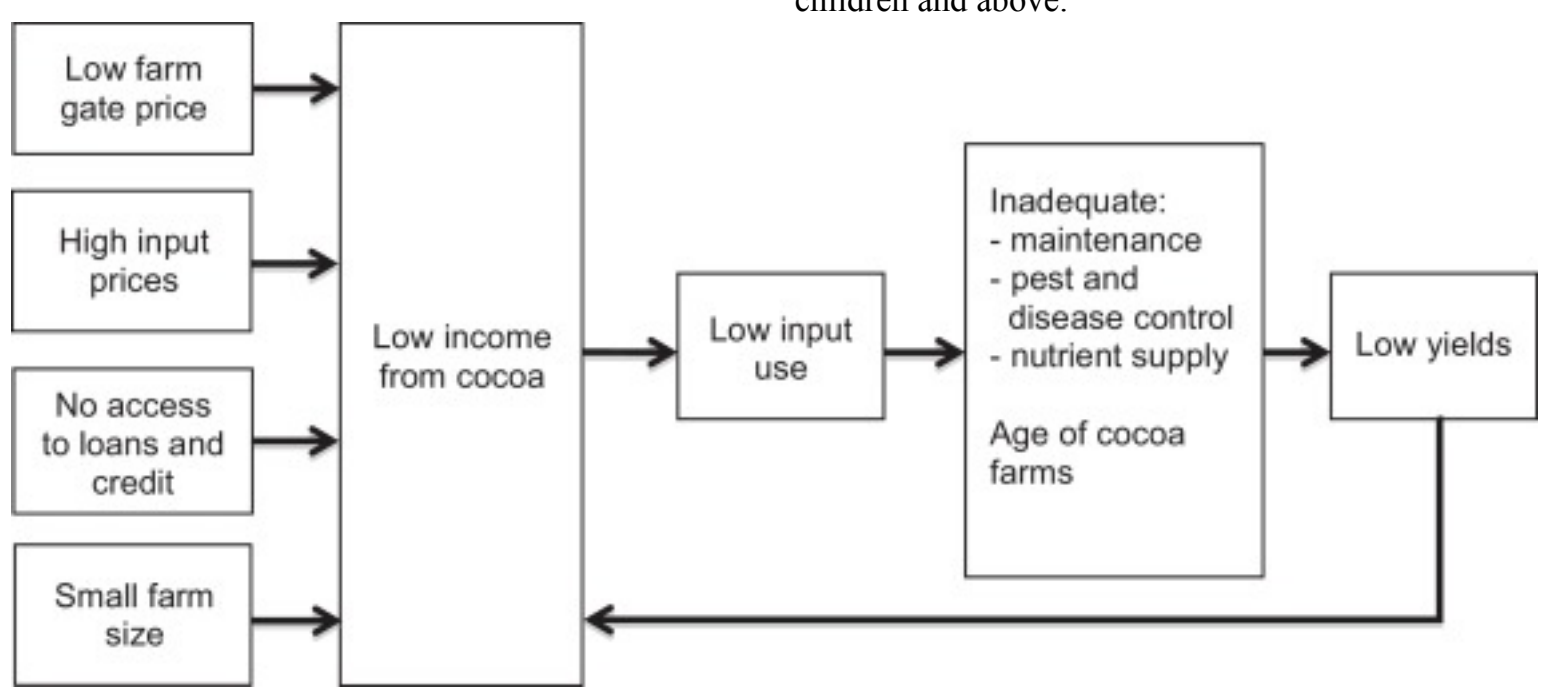

Figure 1. Causes of low yield in farmers' cocoa in West Africa aims at determining why the economic status of Cameroon's rural people are low.

\section{Materials and Methods}

This paper is based on field visits that were carried out in 10 villages in Meme Division, South West Region of Cameroon with at least 5 agro expert volunteers, spending at least one week in these villages and interviewing more than 300 people. These villages include; Matoh Butu, Kwa-Kwa Bakundu, Mabonji Bakundu, Maromba I, Maromba II, Bia Metoko, Matoh Efongoh, Bia Manya and Mabonji and Bia Bekom.

Apart from data about the respondents(Name, Age, Marital status, Occupation, Number of children and name of village) different issues regarding their cocoa production systems were addressed: number of cocoa farms; size of farm(s); number of children involved in agriculture; type of labor used (Hired or family); how much they pay the laborers; if they applied fertilizers and pesticides; how they obtain the chemicals; duration of cocoa fermentation; how they save their income (banks, "njangi" groups, self-savings); how they market their produce(local cocoa vendors, look for markets in cities); how much they cocoa is sold in these places per $\mathrm{Kg}$; how they store their produce; number of bags they produce annually; if keep records and the challenges they encounter in the farms.

The ages of the respondents ranged from 13 to 80 years; average is 42years. As for their occupation, the respondents have farming as their occupation (94.9\%) while the remaining $4.1 \%$ do petty jobs (carpentry, seamstresses, hair dressing etc.). A majority of them are married $(72.6 \%), 15.1 \%$ single, $2.7 \%$ divorced, $8.2 \%$ widows, and $1.4 \%$ widowers. And also, $49.3 \%$ have $0-3$ children, $41.1 \%$ have $4-6$ children and $9.6 \%$ have 7 children and above. 


\section{Results and Discussion}

Farmers in rural areas of Cameroon are mainly small scale farmers. Their cocoa farms are of varied numbers and sizes which can range between 1 farm of up to 8 hectare to 4-8 farms that can be of the same size or more. While some of the farmers own their farms, others take farms on lease and others who do not have enough money to buy their own farmlands, work with the owners of the farm through a system known as "two party" in which the owner of the farm purchases all the farm inputs and they share the profits at the end of the season.

Results show that, these farmers carry out good agricultural practices(from seed selectio, nursing, transplanting right up to harvesting and fermenting) on their cocoa farms and an average farmer in the rural areas produces 32.2bags of cocoa in a season, where each bag weighs about $65 \mathrm{Kg}$. But now, they lack the knowledge to on how to manage their income since there are no banks in the villages. Only $11.2 \%$ save their money in the cities, $25.4 \%$ save in "njanji" group and $64.4 \%$ do not save at all. These make them to mishandle their income and are forced to borrow chemicals for the next planting season causing the buyers to determine the price of the cocoa they produce, hence exploiting them. As a result of no saving too, some farmers lease out their farms for large number of years when faced with a misfortune or they have a celebration or ceremony, consequently, they are left to struggle in hunger until these years elapse.

A majority $(84.1 \%)$ of the farmers borrow chemicals from the buyers while the remaining $15.9 \%$ set aside money to buy chemicals for the next season or they buy just what they can afford. $15.3 \%$ keep detailed record about their farm input, expenses and output while $84.7 \%$ don't. They keep only the records of the amount for the chemicals that they borrowed so that they are not reimbursed in excess during payment. This makes them not to be aware if they are making a lost or gain simply because of unaccountability.

As a result the poor infrastructural nature of the village, where there are no well equipped schools and trained teachers, $80 \%$ of the farmers send their children to secondary school in the cities. Therefore, they are only available to help their parent during the holidays (June to August). The farmers are therefore left to hire laborers assist them in carrying out some activities in their cocoa farms such as clearing, pruning, spraying and even breaking the cocoa pods to extract the cocoa beans. This hiring of the labor is done in two ways; short term and long term. Short term laborers are paid according to man-day and this ranges from 2,000-3,000XAF depending on the activity and the negotiation with the owner but for those who break the cocoa, the wage is $2000 \mathrm{XAF} /$ bucket of fresh cocoa extracted. Long term laborers work for the whole season (that is all the farm operations till harvest) and their wage ranges from 150,000 to $300,000 \mathrm{XAF}$ depending on the size of the farm. This makes them to encure high expenses that are hardly replenished at the end of the season.

The main problem facing rural cocoa farmers is poor roads network linking farm-farm, farm-markets. This makes it difficult for the farmers to look for a better market for their produce. There is also a problem of insecurity from the problem of poor road network where farmers complaint of theft the farm since they cannot easily transport their cocoa beans to a safer location after harvest. This causes some of the farmers(38.9\%) not to ferment their cocoa for the required period coupled to the fact that there are no good ovens to dry their cocoa either because there are no smoke outlets or the smoke outlets have become warn out and has not been replaced.

As a result of the poor road network too, the local buyers has monopolized the market since $84.1 \%$ of the cocoa farmers borrow chemicals from these local buyers. This makes the buyers to decide the price at which they can buy their cocoa coupled to the fact that they have to deduct the money for chemicals borrowed from them with interest. Thus a fluctuating dropping price of cocoa. The farmers also experience pest and disease attack on the crops such as capsid, black pod rot, mealy bugs, aphids, rats and squirrels that eat up the cocoa beans.

The farmers also suffer from high prices of farm inputs such as pesticides, spraying equipments and fertilizers. This is the reason why a few farmers $(22.7 \%)$ do not apply pesticides effectively. Pesticides are applied on a 3month interval and only $2.7 \%$ of the farmers apply fertilizers in their farms and this leads to the degrading fertility of the soil. Because of this, most of the farmers do not accept the cultivation of cassava on their farm since it is a water loving plant although its cultivation can serve as an alternative source of income.

Table 1. price difference of some cocoa chemicals in the different areas

\begin{tabular}{|c|c|c|c|}
\hline $\begin{array}{c}\text { Name of } \\
\text { Chemical }\end{array}$ & $\begin{array}{c}\text { Price at the } \\
\text { city market } \\
\text { (in XAF) }\end{array}$ & $\begin{array}{c}\text { Price at the } \\
\text { village } \\
\text { (in XAF) }\end{array}$ & $\begin{array}{c}\text { price when } \\
\text { borrowed } \\
\text { (in XAF) }\end{array}$ \\
\hline Calomil & 400 & 600 & 1000 \\
\hline O.K Mil & 400 & 600 & 1000 \\
\hline Rodomil Gold & 400 & 600 & 1000 \\
\hline Nordox 40 & 250 & 400 & 600 \\
\hline Nordox 75 & 400 & 600 & 1000 \\
\hline Gamaline & 3500 & 4500 & 8000 \\
\hline
\end{tabular}

The peak season of cocoa is June-August for the light harvest and November-December for the heavy harvest. Last year, 2016 the price of cocoa ranged from 1250XAF 
per $\mathrm{kg}$ for June-August to 900XAF per $\mathrm{kg}$ in November and $800 \mathrm{XAF}$ per $\mathrm{kg}$ in December.

\section{Conclusions}

Rural cocoa farmers in Cameroon have the potential to become rich since the primary cause of their predicament comes from them and within. In order to change their economic status, the farmers have to be educated on better agricultural practices such as the use of organic manure to improve on the soil quality, irrigation channels and the best method to ferment and dry their cocoa. They also have to be thought business management so that they can efficiently manager their farm to encure profits. They have to be encouraged to join and/or create farmers groups that would enable them to better market their produce and how to effectively keep records.

Furthermore, there is need for good infrastructure like roads, ovens to create a more favorable environment for investments and financial transactions in rural areas. Linkages between the rural farmers and producers of farm inputs should be operationalized to establish a better relationship between rural farmers and these institutions. This will help the farmers to buy their farm inputs at cheaper prices. Nevertheless, this requires the collaboration of the rural people and an improvement in their reliability.

\section{Acknowledgement}

I acknowledge my director, Mr. Tcharbuahbokengo NFINN who assisted us financially to carry out our survey. To Moulema Robert, Yangouo Sefoura, Mobit Joshua Mbah, Nkwain Clarisse, Ngepe Elvis, Ngole Wa'ngole, Marceline Awum N, Cheo Pricilla, Ekwo Boris M, Awung Tongwa Pride, Rahufu Pesayap M, Justine Mbongoh, Obi Beryl, Vera Ngong N, Hilary Ashu, Ndam Mfachiken I, Ezo'o Joseph Severin, Nbota Suzane Nawo, Awung Miriam A, Chuo Daizy Yund, Malongam Tadah D, Efamba Peter Modika, Prince Avitus E. Sone, Ebong James, Buna Becky Nyama, Ndobe Rene Ajebe, Besong Nkongho B, Fonga Tabohgow B, Efoe Ekabe, Akum Eliot, Nyouh Karen Chi, Marie-Louise Konde, Noella Kimbi, Mbunya Prudencia, Mbah Melvis, Ngate Emmelien, Atabong N. Pamela, Kolle Edmond, Eyong Manyo B, Eyong Fritz, Mariatu Lawan, Atah Beryl, Leinyuy Mabelt, Numfor Morine, Nkengasong Bridget, Shey Vitalis, Tima Sonita and Nuh Juliana who volunteered to carry out the survey. And to the chiefs of all the villages we went to, who agreed to accommodate us, feed us, secure us and allow us to carry out our survey in their village.

\section{REFERENCES}

[1] Cocoa Research Institute of Ghana (2010): Cocoa Manual. A Source Book for Sustainable Cocoa Production. Ghana Cocoa Board (2010): 41st Annual Report \& Financial Statement for the year ended September, 2010. Pp 19.

[2] Coxhead, I. A., \& Warr, P. G. 1991. Technical Change, Land Quality, and Income Distribution: A General Equilibrium Analysis. American Journal of Agricultural Economics, 73(2), 345-360.

[3] D. Alemagi, L. Duguma, P.A. Minang, M. Feudjio, F. Nkeumoe, Z. Tchoundjeu(2014), Intensification of cocoa agroforestry systems as a REDD+ strategy in Cameroon: hurdles, motivations, and challenges, International Journal of Agricultural Sustainability, p. 19

[4] Datt, G., \& Ravallion, M. 1998. Farm productivity and rural poverty in India. Journal of Development Studies, 34(4), $62-85$.

[5] De Franco, M., \& Godoy, R. 1993. Potato-Led Growth: The Macroeconomic Effects of Technological Innovations in Bolivian Agriculture. Journal of Development Studies, 29(3), 561-587.

[6] Document de Stratégie de Développement du Secteur Rural (DSDR), 2005 (Rural Development Strategy Paper (DSDR), 2005.

[7] Elong, J. G., 2011. L'elite urbaine dans le projet de la relance de la cacaoculture par la SODECAO dans le Cameroun forestier in L'elite Urbain dans l'Espace Agricole Africaine. L'Harmattan (Elong, J. G., 2011. The urban elite in the project to revive cocoa farming by SODECAO in Cameroon forests in L'elite Urbain in the African Agricultural Space. L'Harmattan)

[8] Irz, Xavier, Lin, Lin, Thirtle, Colin, \& Wiggins, Steve. 2001. Agricultural Productivity Growth and Poverty Alleviation. Development Policy Review, 19(4), 449-466.

[9] Nagayets, O. (2005). Small farms: current status and key trends. Paper prepared for the Future of Small Farms Research Workshop. Wye College, June 26-29, 2005.

[10] V. Ngo Nkelle(2007), The sustainability of Cameroon cocoa economy, Presentation at the ICCO roundtable for a sustainable cocoa economy, p. $8 \mathrm{http} / /$ www.icco.org/sites/ www.roundtablecocoa.org/documents/3\%20Mr. $\% 20 \mathrm{Ngo} \%$ 20Nkelle\%20Victor\%20-\%20Cameroon.pdf

[11] World Bank. 2007. World development report 2008: Agriculture for development. Washington, D.C.: World Bank. 